\title{
Assessment of fish post-harvest losses in Tekeze dam and Lake Hashenge fishery associations: northern Ethiopia
}

\author{
Solomon Tesfay ${ }^{*}$ and Mekonen Teferi
}

\begin{abstract}
Background: Fish are perishable and hence susceptible to high post-harvest losses. Post-harvest losses in fisheries include material losses of fish due to spoilage, breakage, size, discarding of by-catches and operational losses. This research was conducted to propose a management strategy to reduce post-harvest losses suffered by Tekeze dam and Lake Hashenge fishery associations.

Methods: This research was conducted in Tekeze dam and Lake Hashenge fishery associations. The data were collected from primary and secondary quantifiable information on post-harvest losses. A total of eight official associations were surveyed during the study period.

Results: Each of these associations was found to own at least a refrigerator and a boat with $(7.67 \pm 3.82)$ nets. The mean $( \pm S D)$ number of refrigerators owned at present is $(11.13 \pm 10.09)$, and $94.9 \%$ of the respondents involved in the study were males. Fish loss and yield per year of the associations showed a positive strong significant correlation $(r=0.948, d f=6, p<0.01)$.

Conclusion: Physical loss was the most common loss observed causing high economic loss. Improvement of facilities from the point of production until it reaches the consumer is vital, and fish must be stored and distributed under chilled temperature conditions.
\end{abstract}

Keywords: Post-harvest, Losses, Fish, Spoilage, Physical loss, By-catch

\section{Background}

Post-harvest fish losses can be defined as nutrient or economic losses render the commodity unavailable or nutritionally deficient for human utilization. Losses can be categorized into physical, quality and market force loss [1]. Traditional processing can cause depletion in nutrient availability, leading to nutritional loss. Cheke and Ward [2] explained a more pragmatic classification of fish loss into four common categories: physical loss, quality loss, nutritional loss and market force loss.

Fisheries play an important contribution to the animal protein supplies of many communities in both the industrialized and developing world [3] and provide

*Correspondence: solomon232000@yahoo.com Department of Biology, College of Natural and Computational Sciences, Mekelle University, PO Box 231, Mekelle, Ethiopia the main source of animal protein for about one billion people globally. Fisheries are an important part of food security and nutrition, particularly for many poor people in developing countries. In low-income food-deficient countries (LIFDCs), they make up $22 \%$ of animal protein consumption overall $[4,5]$. In coastal areas and around major river systems, the dependence on fish is usually higher $[5,6]$. Fish are perishable and hence susceptible to high post-harvest losses if intervention measures are not put in place. Fish losses are among the highest in comparison with all other commodities in the entire food production system [5]. Post-harvest losses in fisheries include material losses of fish due to spoilage, fragmentation, size, discards of by-catch and operational losses [7, 8]. Both physical [9] and quality [8] losses are high in the fisheries sector [8], and these translate into losses in the nutritional contribution of fish to the diet and health of 
populations [10]. A review of case studies on post-harvest losses in several countries in Africa indicated high levels of losses both in quantity (material or physical losses) and in quality (mostly due to downgrading) of fishery products [8]. There are also losses of value, what the fish is worth in monetary terms, losses of quality, when stale fish become less attractive to consumers, losses in nutritional value, when the fish contribute less towards the diet of consumers than it otherwise would [7]. For example, according to FAO [8], physical and quality post-harvest losses in mukene (Rastrineobola argentea) fisheries alone are valued at $0-7.5$ and $1.5-18.9 \%$ in Kenya, 20-40 and $20 \%$ in Tanzania, and $26-40$ and $2-5 \%$ in Uganda, respectively. These losses have major implications for the nutritional quality and availability of fish products to local populations.

In addition, fish spoil very quickly as a result of intrinsic and extrinsic factors $[11,12]$. High ambient temperatures hasten fish spoilage by accelerating the activities of bacteria, enzymes and chemical oxidation of fat in fish flesh. Unwholesome fish may be discarded by fisher folk at different stages of handling and processing leading to economic and nutritional loss in the fishing industry [11].

Post-harvest losses occur at different points from capture to marketing, and in some fisheries the level of losses could be considerable; for example, downgrading of fish because of spoilage is perhaps as high as $10 \%$ and more [13]. FAO [11] has estimated post-harvest losses in developing countries to be up to $50 \%$ of domestic fish production. For example, in Nigeria, post-harvest losses have been estimated as 50\% [14] and 30-50\% [15]. According to Teklu [16], Ethiopia loses one-third of its annual production and this was about 10,000 tons of fish per annum among 28,000 tons of production.

Post-harvest fish losses are often caused by biochemical and microbiological spoilage changes that occur in fish after death. A live fish has natural defence mechanisms that help to prevent spoilage. However, once a fish dies, its defence mechanisms stop and enzymatic, oxidative and microbiological spoilage begins to cause quality deterioration [17].

Moreover, fish is also a high protein product which makes it susceptible to rapid degradation by microorganisms. Factors that are associated with microbial spoilage are method of catch, type of fish, sanitation, processing and storage conditions. Microbial spoilage is estimated to cause physical losses amounting to about $10 \%$ of fish catches worldwide [18], and hence it has impacts on the availability of nutrients from fish products. It is therefore a product that needs proper handling and processing in order to preserve nutrients and its functional components that promote good health [18].
Consecutively to provide more precise information on the losses during the various stages of fish production (capture to marketing), lake (dam)-specific studies are needed. Globally, when management strategies are proposed for a fishery, adequate consideration is often not given to the very important aspect of post-harvest losses. In Ethiopia, particularly in Tigray Regional State, there is a lack of information on fishery management and postharvest interventions that have been recommended for reducing Tekeze dam and Lake Hashenge fish post-harvest losses.

The aims of this survey was to (1) identify and measure the kinds and extent of fish post-harvest losses being experienced by the fishery associations; (2) list the major reasons for fish post-harvest losses; (3) evaluate the local knowledge, attitude and practices (KAP) about fish postharvest losses; (4) compare and observe the status of fish post-harvest loss between the two water bodies; and (5) suggest strategies for reducing post-harvest losses by the fisheries and to propose actions to prevent them.

\section{Methods \\ Description of study areas}

The study was conducted in two water bodies of Tigray, northern Ethiopia; Tekeze dam and Lake Hashenge. Tekeze dam is a hydroelectric dam on the Tekeze River, a tributary of the Nile that flows through one of the deepest gorges in the world and is $608 \mathrm{~km}$ long [19]. The gorge (canyon) which it has created is the deepest in Africa and one of the deepest in the world, at some points having a depth of over $2000 \mathrm{~m}$. Tekeze River rises in the central Ethiopian Highlands near Mount Qachen within Lasta, at $14^{\circ} 11^{\prime} \mathrm{N} 37^{\circ} 31.7^{\prime} \mathrm{E}$. The Dam is approximately $155 \mathrm{~km}$ from Mekelle city [20]. Lake Hashenge is one of the highland lakes at an altitude of $2440 \mathrm{~m}$ above sea level located between $13^{\circ} 86^{\prime}-13^{\circ} 99^{\prime} \mathrm{N}$ and $5^{\circ} 51^{\prime}-5^{\circ} 59^{\prime} \mathrm{E}$ in Ofla Woreda Southern Tigray Administrative Zone about $628 \mathrm{~km}$ north of Addis Ababa and about $152 \mathrm{~km}$ south of Mekelle and $8 \mathrm{~km}$ north of Korem town. The surface area and maximum depth of the lake are $20 \mathrm{~km}^{2}$ and $25 \mathrm{~m}$, respectively [21].

\section{Data collection}

Primary and related secondary data were collected from the fishery associations of Tekeze dam and Lake Hashenge. Out of 302 legal fisherfolk, 254 were interviewed using QLAM [1]. Since the total population for each association's respondents could not be found together, random sampling was not possible. Instead, respondents available at the times of the visits were interviewed within a given period. The field survey was conducted from January to June, 2015. Ahead of starting 
data collection, the objectives of the research were clearly explained to each respondent, their offices and their Wereda Administration offices. Accordingly, they all genuinely accepted our request to conduct interviews and collect other primary information. All responsible bodies in the university where we are working, both Wereda Administration offices of study areas and each participant involved in this study gave an approval for the collection and dissemination of the information.

Secondary data from fisheries documents, annual reports and related documents were assessed. Other information on the overall fisheries activities was obtained through observation and discussion with fishermen and Wereda fishery experts. Our observations included road surveys for spoiled fish thrown away and counting or estimating these losses to the nearest $\mathrm{kg}$ or quintal $(=100 \mathrm{~kg})$.

The data collection sites at the Tekeze dam were at Ariqua, Gilidu and Chiresh gorges where most of the fishery associations had different landing sites. At Lake Hashenge the fishery associations had three major landing sites known as Adi Golo, Menkere and Adi-Abomossa. The fish species the associations handling in Tekeze dam were Nile tilapia (Oreochromis niloticus), cat fish and barbus species. In Lake Hashenge, the fish species were common carp (Cyprinus carpio) and Nile tilapia (Oreochromis niloticus).

\section{Data analysis}

The tools of analysis used for this study are descriptive statistics of the Explanatory Variables (both qualitative and quantitative) using SPSS16 software. These involve the use of central tendency including the mean, frequency distribution and percentages.

\section{Results}

\section{Characteristics of the associations}

A total of eight associations were surveyed during the study, and each association was found to own at least a refrigerator and a boat with varied number of nets. On the other hand, the mean number of individuals working together as fisherfolk was 44.25 , and the mean number of boats was almost the same as its standard deviation $(21.5 \pm 21)$ because the number of boats owned by the associations varied from 1 to 67 (Table 1).

In addition, we found a significant and positive correlation between total members of each association with number of boats and refrigerators they owned $(r=0.806$, $d f=6, p<0.05)$ and $(r=0.863, d f=6, p<0.01)$, respectively. The yield per year and loss per year were also significantly correlated with number of boats and yield per year $(r=0.786, d f=6, p<0.05)$ and $(r=0.948, d f=6$, $p<0.01$ ), respectively. Moreover, the number of refrigerators and number of boats owned were significantly positively correlated $(r=0.938, d f=6, p<0.01)$ (Table 2$)$.

\section{Demographic information}

About 241 (94.9\%) of the fisherfolk involved in the study were males. A majority of the respondents involved in this sector worked full time, and $34.3 \%$ of them were educated to grade 5-8. A modest proportion of the respondents $(24.3 \%)$ were aged between 20 and 24 years old, while about $75 \%$ of the remaining respondents were younger or older than the aforementioned age range, that is, 14.1 and $61.1 \%$, respectively (Table 3 ).

\section{Types of fish post-harvest losses}

Physical loss is a catch not used after harvest which was the major type of losses in our study areas. For example $42.9 \%$ of the respondents reported the loss of 1 jerry can (about $20 \mathrm{~kg}$ ) out of 10 jerry cans of a catch that was spoiled before landing. Moreover, $46.5 \%$ of the respondents reported the highest proportion of fish loads damaged upon reaching the market was $1-3 \mathrm{~kg}$ out of one sack, though $3.2 \%$ of them did not report incurring such losses (Table 4).

Quality loss is the lower grade of the harvest with a decreased price, but in our case nobody could sell a

Table 1 Characteristics of the fishery associations of Tekeze dam and Lake Hashenge surveyed for the major equipments in hand or in use

\begin{tabular}{|c|c|c|c|}
\hline Variables & $\begin{array}{l}\text { Both }(n=254) \\
(\bar{X} \pm \text { SD })\end{array}$ & $\begin{array}{l}\text { Tekeze }(n=228) \\
(\bar{X} \pm S D)\end{array}$ & $\begin{array}{l}\text { Hashenge }(n=26) \\
(\bar{X} \pm S D)\end{array}$ \\
\hline Number of fisherfolk & $44.25 \pm 23.28$ & $54 \pm 17.34$ & $15 \pm 2.83$ \\
\hline Number of boats & $21.5 \pm 21$ & $27.83 \pm 21.8$ & $1 \pm 0.00$ \\
\hline Number of nets per boat & $7.67 \pm 3.82$ & $7.98 \pm 3.82$ & $5.12 \pm 3.82$ \\
\hline Number of refrigerators owned at present & $11.13 \pm 10.09$ & $14.5 \pm 9.4$ & $0 \pm 0.00$ \\
\hline
\end{tabular}


Table 2 Correlation table of the fishery associations of Tekeze dam and Lake Hashenge surveyed for the major equipments in hand or in use during 2015

\begin{tabular}{|c|c|c|c|c|c|c|}
\hline & Members & Boats & Refrigerators & Nets/boat & Yield/year & Lost/year \\
\hline \multicolumn{7}{|l|}{ Members } \\
\hline$r$ value & 1 & $0.806^{*}$ & $0.863^{* *}$ & 0.433 & 0.635 & 0.474 \\
\hline$p$ value & & 0.016 & 0.006 & 0.284 & 0.091 & 0.235 \\
\hline \multicolumn{7}{|l|}{ Boats } \\
\hline rvalue & $0.806^{*}$ & 1 & $0.938^{* *}$ & 0.628 & $0.786^{*}$ & 0.591 \\
\hline$p$ value & 0.016 & & 0.001 & 0.095 & 0.021 & 0.123 \\
\hline \multicolumn{7}{|c|}{ Refrigerators } \\
\hline$r$ value & $0.863^{* *}$ & $0.938^{* *}$ & 1 & 0.621 & 0.567 & 0.328 \\
\hline$p$ value & 0.006 & 0.001 & & 0.100 & 0.143 & 0.428 \\
\hline \multicolumn{7}{|c|}{ Nets/boat } \\
\hline rvalue & 0.433 & 0.628 & 0.621 & 1 & 0.452 & 0.358 \\
\hline$p$ value & 0.284 & 0.095 & 0.100 & & 0.260 & 0.384 \\
\hline \multicolumn{7}{|c|}{ Yield/year } \\
\hline$r$ value & 0.635 & $0.786^{*}$ & 0.567 & 0.452 & 1 & $0.948^{* *}$ \\
\hline$p$ value & 0.091 & 0.021 & 0.143 & 0.260 & & 0.000 \\
\hline \multicolumn{7}{|l|}{ Lost/year } \\
\hline$r$ value & 0.474 & 0.591 & 0.328 & 0.358 & $0.948^{* *}$ & 1 \\
\hline$p$ value & 0.235 & 0.123 & 0.428 & 0.384 & 0.000 & \\
\hline
\end{tabular}

N.B: ${ }^{*}$ Correlation is significant at the 0.05 level (2-tailed); ${ }^{*}$ Correlation is significant at the 0.01 level (2-tailed)

Table 3 Demographic information on respondents of Tekeze dam and Lake Hashenge fishery associations

\begin{tabular}{|c|c|c|c|}
\hline & No (\%) & & No (\%) \\
\hline \multicolumn{4}{|l|}{ Variables $(n=254)$} \\
\hline Age range in years & & Education & \\
\hline $15-19$ & $36(14.1)$ & Illiterate & $61(24)$ \\
\hline $20-24$ & $62(24.3)$ & $1-4$ & $70(27.6)$ \\
\hline $25-29$ & $32(12.5)$ & $5-8$ & $87(34.3)$ \\
\hline $30-34$ & $39(15.3)$ & $9-10$ & $36(14.2)$ \\
\hline $35-39$ & $36(14.1)$ & Above 10 & 0 \\
\hline $40-44$ & $22(8.6)$ & & \\
\hline $45-49$ & $14(5.5)$ & Occupation & \\
\hline $50-54$ & $10(3.9)$ & Full time & $299(90.2)$ \\
\hline $55-59$ & $2(0.8)$ & Additional $^{a}$ & $25(9.8)$ \\
\hline $60-64$ & $1(0.4)$ & & \\
\hline \multicolumn{4}{|l|}{ Sex } \\
\hline Male & $241(94.9)$ & & \\
\hline Female & $13(5.1)$ & & \\
\hline
\end{tabular}

N.B:1-4 = first cycle (primary school), 5-8 = second cycle (junior school) and $9-10=$ secondary school

a Includes agriculture, trade and guards in different offices

spoiled product (lower-quality fish) with a lower price. The only alternative is to throw the fish away or to use for own domestic purposes if in small quantities. Among the respondents, majority of them (84.3\%) supported the idea of throwing the fish away (Table 4).
The third type of post-harvest loss is market force loss caused by unexpected market demand and supply forces. Some of our respondents explained that illegal fishermen and associations sold their products at lower prices, which was challenging for the legal operators. There were also competitions in price among the fishery associations and fish traders. These cause operators to sell their product at a price below expectations.

In addition, during our survey from January to June we estimated or measured about 112.98 quintals of fish postharvest loss as physical loss (Fig. 1). This figure would be much higher if the fish were thrown away far distant from our sites and buried and the subsequent marketing losses are included. Using the current price of 45 Ethiopian birr per $\mathrm{kg}(\$ 2.11 / \mathrm{kg})$ at Yechila, the monetary or economic loss was estimated to be 508,410 Ethiopian birr $(\$ 25,420.5)$.

The types, extent and seasons of fish post-harvest losses in the study areas revealed a serious problem that needs urgent intervention to reduce them. In addition, the time and energy spent and the cost of fuel and other expenditures will not be covered if the loss is higher than the gain. In Tekeze dam, the temperatures were very high and when compounded with other factors the post-harvest losses correspondingly increase. In contrast, Lake Hashenge is located in the highlands with only two associations and limited products. Although there were transport and other infrastructure problems, the fishery 
Table 4 Types, extents and seasons of fish post-harvest losses

\begin{tabular}{|c|c|c|c|}
\hline Variables $(n=254)$ & No. (\%) & Variables $(n=254)$ & No. (\%) \\
\hline Proportion of catch spoils before landing & & \multicolumn{2}{|c|}{ The storage time of your processed fish before sending to the market } \\
\hline 1 jerry can out of 10 jerry cans & $109(42.9)$ & 1 day & $43(16.9)$ \\
\hline 2 jerry cans out of 10 jerry cans & $41(16.1)$ & 1 week & $56(22)$ \\
\hline 3 jerry cans out of 10 jerry cans & $13(5.1)$ & 2 weeks & $91(35.8)$ \\
\hline Above 3 jerry cans out of 10 jerry cans & $16(6.3)$ & 1 month & $43(16.9)$ \\
\hline Others & $75(29.5)$ & More than 1 month & $21(8.3)$ \\
\hline Proportion fish load damaged upon reaching the market & & Do you get (face) post-harvest fish losses? & \\
\hline $1-3 \mathrm{~kg}$ out of one sack & $118(46.5)$ & Yes & $235(92.5)$ \\
\hline $4-6 \mathrm{~kg}$ out of one sack & $21(8.3)$ & No & $19(7.5)$ \\
\hline $7-8 \mathrm{~kg}$ out of one sack & $12(4.7)$ & \multicolumn{2}{|c|}{$\begin{array}{l}\text { Have you incur loss due to submerged nettings or sudden fell down of vessels } \\
\text { from boat? }\end{array}$} \\
\hline $10 \mathrm{~kg}$ and above out of one sack & $95(37.4)$ & Yes & $195(76.8)$ \\
\hline We didn't face fish damage/no spoil fish & $8(3.2)$ & No & $59(23.2)$ \\
\hline When do you mostly incur losses? & & \multicolumn{2}{|c|}{ Did you throw any fish into the lake before landing because of spoilage? } \\
\hline During fresh fish handling & $68(26.8)$ & Yes & $66(26)$ \\
\hline During processing & $27(10.6)$ & No & $188(74)$ \\
\hline During storage & $132(52)$ & \multicolumn{2}{|l|}{ How often did you discard fish during the last 6 months? } \\
\hline During distribution & $27(10.6)$ & Never & $13(5.1)$ \\
\hline During which season do you incur high losses? & & Once & $14(5.5)$ \\
\hline During January & $45(17.7)$ & Twice & $43(16.9)$ \\
\hline During April & $47(18.5)$ & More than twice & $184(72.4)$ \\
\hline During July & $118(46.5)$ & \multicolumn{2}{|l|}{ Do you get lower price due to low quality of fish? } \\
\hline During October & $4(1.6)$ & Yes & $40(15.7)$ \\
\hline Others & $40(15.7)$ & No & $214(84.3)$ \\
\hline
\end{tabular}

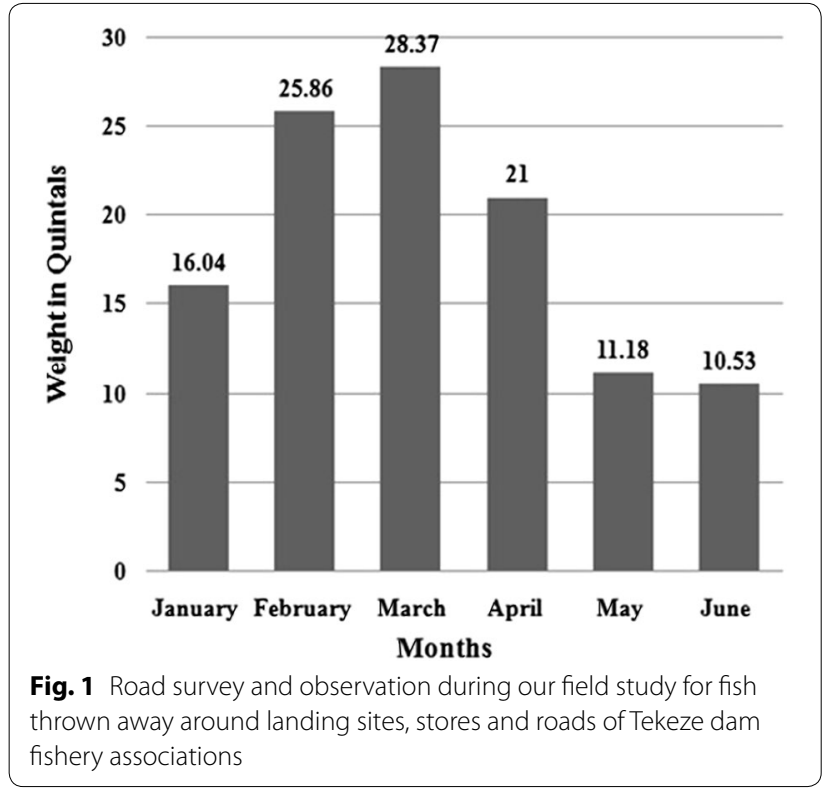

associations experienced lower post-harvest losses. In the highlands, the temperature is fairly low and rate of fish spoilage is slowed down drastically. But the nets can be deployed for up to 3 days without hauling up causing some fish loss to early fish deaths in the nets which was usually considered as by-catch or spoiled.

\section{Reasons for fish post-harvest losses}

According to the respondents and our observations, there were several reasons that contributed to fish postharvest losses. Among these were infrastructure-related problems like shortage of refrigerators, transport and power fluctuations as shown in Table 5. Over production, over-stuffed of refrigerators (poor storage) and mixing of the new with the old product also cause losses.

In addition, pre-harvest losses due to the long times that the nets were set or early fish death in the net before hauling of nets causes spoilage of fishes. This usually happens as a result of delay to haul nets, waves and sudden rises in water level during floods.

Some of the causes of fish post-harvest losses are natural, such as high temperature (20.5\%), distance and geographic problems (Table 5).

Moreover, we assessed the level of agreement between different respondents regarding the contributory factors to post-harvest losses in the fishery and it was found that $67.3 \%$ of respondents strongly agreed that long hours 
Table 5 Major reasons that cause fish post-harvest losses

\begin{tabular}{lc}
\hline Variables $(\boldsymbol{n}=\mathbf{2 5 4})$ & No. (\%) \\
\hline Infrastructure problems & $147(57.8)$ \\
Harvested fish delay in store (lack of market) & $34(13.4)$ \\
High temperature & $52(20.5)$ \\
Distance and geographic problem & $12(4.7)$ \\
Increasing number of boats & $5(2)$ \\
I do not know & $4(1.6)$ \\
\hline
\end{tabular}

of setting gear before hauling caused high post-harvest quality loss and $66.1 \%$ of them strongly disagreed on the location of the store as it was not accessible to their fishing ground or processing area (Table 6).

\section{The economic impact of post-harvest loss on the small-scale fishery associations}

Poor-quality fish constitutes an economic loss to fishermen and fish traders. If losses are quantified, it would be possible to verify at what stages of value-chain, serious losses occur and so pay adequate attention to the mechanisms or technologies that can be put in place to reduce losses at these stages. This would have a more direct impact on the fishery. The total costs and profits of the fishery associations in the study lakes were not calculated. But qualitatively, the major cost for the fisheries included boat, motor, benzene, refrigerators, gear (gill nets, hooks), packing materials (e.g. plastic), labour costs for fishing and processing and also transportation costs.

\section{Knowledge, attitude and handling practice (KAP) of the society about fish post-harvest losses}

According to the respondents, $64.2 \%$ of them had regular times for setting, checking and hauling of the fishing nets. Based on their responses, fish processing (filleting and gutting) was done under shade, under trees or in a cave, where quality post-harvest loss is possibly reduced.
However, $79.9 \%$ the respondents did not receive technical training related to fish quality and handling. But they could easily distinguish between the spoiled fish and unspoiled fish. About $96.9 \%$ of them not only know this but they could also characterize losses using the signs and colour changes (Table 7). The colour changes in scales or gills, eyes, texture and bad smell due to spoilage are among the signs the fishermen used to distinguish between bad and good fish quality. In our survey, most of the respondents explained and showed us practically that spoiled fish flesh becomes greenish, cloudy and whitish with a very soft texture and deteriorated appearance (Fig. 2a). In addition, the eye of spoiled raw fish becomes cloudy or dull and the gills' colour and texture become yellowish brown and rough, respectively (Fig. 2b).

Generally, there seem to be no problem with knowledge, altitude and fish handling practices theoretically, but practically, it is doubtful.

\section{Possible intervention strategies and managements of fish post-harvest losses}

Interventions to reduce fish post-harvest losses are crucial, and some of the potential intervention strategies are listed in Table 8 with their corresponding frequency and percentage values. For example, $55.1 \%$ of the respondents tried to overcome fish post-harvest losses by decreasing production when refrigerators are full, making good arrangements and management of refrigerators. A total of $53.2 \%$ of the respondents proposed interventions such as quickly reaching to storage area and refrigerated immediately, controlling refrigerators and separating the spoiled and healthy ones, reducing production and by increasing number of refrigerators.

\section{Preservation techniques}

According to the respondents and based on our observation, there were no chemical treatments or preservation

Table 6 Data generated by questions using a six-point Likert continuum analysis involving calculating percentages from the raw data

\begin{tabular}{|c|c|c|c|c|c|}
\hline \multirow[t]{2}{*}{ Value statement } & \multicolumn{5}{|c|}{ Percent responses $\left(n^{a}=254\right)$} \\
\hline & Strongly agree & Agree & Neither & Disagree & Strongly disagree \\
\hline Long hours of setting gear before hauling causes high post-harvest quality loss & 67.3 & 28.7 & 2.8 & 1.2 & 0 \\
\hline Fishers from distant fishing grounds land large quantities of spoiled fish & 49.2 & 41.3 & 3.9 & 5.5 & 0 \\
\hline High post-harvest fish loss occurs during rainy season & 47.2 & 34.3 & 14.2 & 4.3 & 0 \\
\hline The store is accessibly located to your fishing ground or area & 4.7 & 9.4 & 5.1 & 14.6 & 66.1 \\
\hline Fish post-harvest loss and spoilage happens even after refrigerated & 37.8 & 39.8 & 5.5 & 9.5 & 2 \\
\hline Small fishes are easily spoiled and cause low quality product & 38.6 & 24.8 & 22 & 14.2 & 0.4 \\
\hline
\end{tabular}

a Number of respondents 
Table 7 List of variables related: knowledge, attitude and handling practice (KAP) of the society about fish postharvest losses

\begin{tabular}{|c|c|}
\hline Variables $(n=254)$ & No. (\%) \\
\hline \multicolumn{2}{|c|}{$\begin{array}{l}\text { Do you have regular time of setting, checking and hauling (removing) } \\
\text { the fishing nets? }\end{array}$} \\
\hline Yes & $163(64.2)$ \\
\hline No & $91(35.8)$ \\
\hline \multicolumn{2}{|c|}{$\begin{array}{l}\text { How do you keep your fish cool during processing (filleting and gut- } \\
\text { ting) in your working area (fishing ground) }\end{array}$} \\
\hline $\begin{array}{l}\text { In shady area(under tree, under caves) or using woods and } \\
\text { clothes }\end{array}$ & $168(66.1)$ \\
\hline $\begin{array}{l}\text { In cool area/air of night, early morning and well-ventilated } \\
\text { areas }\end{array}$ & $76(29.9)$ \\
\hline By putting in sacks or jerry cans & $6(2.4)$ \\
\hline Nothing & $4(1.6)$ \\
\hline \multicolumn{2}{|l|}{ How do you keep your fish cool during transport? } \\
\hline In the jerry cans by covering them with sack/inside sacks & $138(54.3)$ \\
\hline $\begin{array}{l}\text { Putting under the boats chair which is cool and shady or } \\
\text { ventilated area }\end{array}$ & $93(36.6)$ \\
\hline Both & $11(4.3)$ \\
\hline No means & $12(4.7)$ \\
\hline \multicolumn{2}{|l|}{ Do you wash your fish after harvest? } \\
\hline Yes & $107(42.1)$ \\
\hline No & $147(57.9)$ \\
\hline \multicolumn{2}{|l|}{ How long are you involved in fishing/fish trading? } \\
\hline $1-3$ years & $206(81)$ \\
\hline $4-7$ years & $38(15)$ \\
\hline$>7$ years & $10(4)$ \\
\hline \multicolumn{2}{|l|}{ Have you received any training on fish quality? } \\
\hline Yes & $51(20.1)$ \\
\hline No & $203(79.9)$ \\
\hline \multicolumn{2}{|l|}{ Do you observe any change in your fish during harvest? } \\
\hline Yes & $246(96.9)$ \\
\hline No & $8(3.1)$ \\
\hline
\end{tabular}

practices to protect fish from post-harvest losses for commercial purposes except refrigeration. With regard to alternative practices such as drying and to a lesser extent salting, all respondents of all associations' answered "No" to a question asking "Is drying, smoking and salting common in your area?" In addition, they explained that they never had experience of these preservation techniques for their raw or processed fish in their associations. However, there was one association that had an experience of drying for few months and the post-harvest losses were huge which was attributed to inappropriate drying, handling and storage techniques. At the fishing grounds, use of ice (cooling box) for fish after harvest or before it reaches the stores was uncommon, and $98.8 \%$ of the respondents explained that they did not use cooling boxes (Table 9).

\section{Secondary-data-based fish post-harvest loses} and economic loss assessments

Secondary data on post-harvest losses collected from the offices of the fishery associations and traders of the study lakes showed continuing non-management of fish post-harvest losses. Based on their reports, out of the total product of 29,537.9 quintals, 1071.68 quintals were lost and the estimated monetary loss was 4,822,560 birr $(\$ 225,765.45)$ at $45 \mathrm{birr} / \mathrm{kg}(\$ 2.11 / \mathrm{kg})$, the current price in the study areas (Table 10).

\section{The status of fish post-harvest loss between Tekeze dam and Lake Hashenge fishery associations}

Based on our observations, secondary data and the information from the respondents fish post-harvest loss was significantly higher in Tekeze dam than Lake Hashenge $(t=-3.947, d f=6, p<0.01)$. Lake Hashenge is a relatively cold highland lake where mean monthly air temperature and rain fall vary from 13 to $19{ }^{\circ} \mathrm{C}$ and from 0.0 to $250 \mathrm{~mm}$, respectively, and the possibility of fish postharvest loss was low. Tekeze dam was constructed in lowland where it is relatively very hot with mean monthly air temperature and rain fall ranging from 22.25 to $31.15^{\circ} \mathrm{C}$ and from 0.0 to $8.6 \mathrm{~mm}$, respectively, which accelerates fish spoilage and causes the highest fish post-harvest losses. Operational losses were also higher in Tekeze; there were a lot of fish scales, bones, gills and guts thrown away at their landing sites, where they operate their fishes, creating a bad smell for the fisher folk. Still now there is no any trial to use these parts for either domestic animal's feed or agricultural uses; however, some of the associations have a plan and one of them asks some help to our institution. In contrast, at Lake Hashenge the production was low and the operational losses were also low as they did not discard any part of the fish except the gut contents (they usually sold gutted fresh fish) and the gills were collected for their cats and dogs. At Lake Hashenge, the most probable cause of fish post-harvest loss was the prolonged time of hauling up the nets which was up to three days. But there is no part of fish lost except the gut parts. The nets commonly used in Tekeze are monofilament gill nets where as in Lake Hashenge are the commercial double-strand gill nets.

\section{Discussion}

Throughout the study in the entire eight legal fishery associations, most of the fishermen were relatively young aged between 20 and 24 years. We assume this is because fishing is a difficult job which needs labour and takes many hours, some of them in the cold at night particularly in Tekeze. Similar observations were reported by Kenyan researchers [22]. But the educational back grounds of the respondents were greater than Omwega 

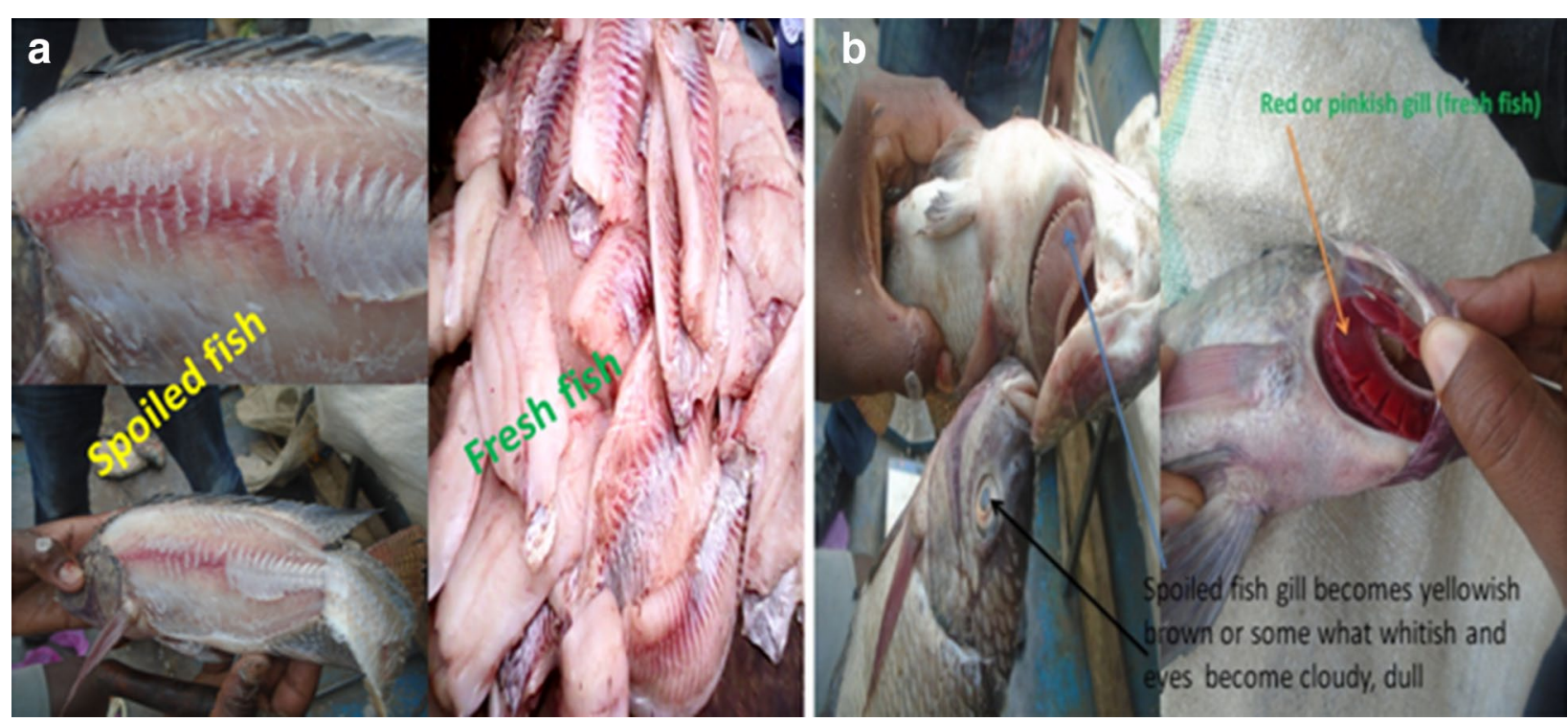

Fig. 2 Comparison of spoiled raw fish and filleted fresh fish in Tekeze dam. This is one of the ways to separate the fish qualities visually or through organoleptic (sensory) measurement of spoilage (a) and using their eyes and gills (b)

Table 8 List of variables intervention of fish post-harvest loss

\begin{tabular}{|c|c|}
\hline Variables $(n=254)$ & No. (\%) \\
\hline \multicolumn{2}{|l|}{ How do you overcome loss } \\
\hline $\begin{array}{l}\text { Decrease production when refrigerators are full, Good } \\
\text { arrangements and management of refrigerators }\end{array}$ & $140(55.1)$ \\
\hline I don't know, not solved still now & $39(15.4)$ \\
\hline $\begin{array}{l}\text { By increasing number of refrigerators and by using genera- } \\
\text { tor }\end{array}$ & $32(12.6)$ \\
\hline Reach on time to refrigerators & $28(11)$ \\
\hline I didn't face post-harvest loss & $15(5.9)$ \\
\hline \multicolumn{2}{|l|}{$\begin{array}{l}\text { Describe how you and people in your area have tried to reduce fish } \\
\text { post-harvest losses }\end{array}$} \\
\hline $\begin{array}{l}\text { By quickly reaching to storage area and refrigerated immedi- } \\
\text { ately, by controlling refrigerators and separate the spoiled } \\
\text { and healthy once, by reducing production and by adding } \\
\text { refrigerators }\end{array}$ & $135(53.2)$ \\
\hline $\begin{array}{l}\text { By communicating each other, giving assignments and } \\
\text { responsibilities, by accomplishing our operations early in } \\
\text { the morning and doing in cool and shady area, reducing } \\
\text { exposure of the harvest from high temperature and by } \\
\text { keeping the meat clean, no more sleep after deploying } \\
\text { the net, operate quickly }\end{array}$ & $75(29.5)$ \\
\hline By increasing human power during highest production time & $5(2)$ \\
\hline I don't know, no change yet, no means yet & $37(14.6)$ \\
\hline
\end{tabular}

and his friend's findings. He found out that majority of the fishermen (60.9\%) had only primary level education, but in our case $48.5 \%$ of the respondents were in the second cycle and above.

Losses can be categorized into physical, quality and market force loss [1]. Our finding on physical loss indicated that in every $200 \mathrm{~kg}$ of a catch, there were about $20 \mathrm{~kg}$ of loss as result of spoilage before landing and the highest proportion of fish loads damaged upon reaching the market was $1-3 \mathrm{~kg}$ out of one sack which is $46.5 \%$. Concerning the quality loss, $84.3 \%$ of the respondents supported the idea of throwing lower grade of the harvest as it causes a decreased price. Similarly, other studies have estimated losses at about 5-87\% quality losses occur along entire fish value chains due to discoloration, bad weather, damage during handling and transportation, insect infestation and spoilage, depending on the fish species $[1,2,23]$. Such losses culminate into income losses that could exceed $32-50 \%$ of domestic fish catch $[2,23]$. Besides loss of revenue, a main manifestation of quality deterioration is nutrient degradation and bio-contamination, meaning loss of food value and occurrence of food-borne health hazards [24]. A quality improvement is normally associated with a price increase and perhaps the most significant question is who is ultimately going to bear this price increase? "Quality is a highly subjective concept and absolute measures do not exist. However, if fish does not represent a public health risk and is eaten by consumers, it is surely of acceptable quality. The question therefore remains as to what extent development projects should become involved in upgrading the quality of fish, thereby pricing them out of the market for the low-income consumer" [25]. Market force loss was not as such a problem, but there are losses as a result of competition in price; as loss is the difference between the expected price and the actual price, there are illegal fishery groups who sold their product in lower price which 
Table 9 Variables related to preservation

\begin{tabular}{|c|c|c|}
\hline Variable $(n=254)$ & Yes & No \\
\hline $\begin{array}{l}\text { Do you use ice (cooling box) in fish after harvest or before you reach your store (where } \\
\text { refrigerator is available)? }\end{array}$ & $3(1.2 \%)$ & $251(98.8 \%)$ \\
\hline Is drying, smoking and salting common in this area? & $0(0 \%)$ & $254(100 \%)$ \\
\hline Name some chemicals that can be used to maintain fish quality & All say we never use any chemical & \\
\hline $\begin{array}{l}\text { What type of fish (meat) preservation (processing) techniques you exercise or use in your } \\
\text { association or area? }\end{array}$ & All say we never use any except refrigerator & \\
\hline
\end{tabular}

Table 10 Secondary data on post-harvest losses collected from the offices of the fishery associations, shares and traders of the study lakes

\begin{tabular}{|c|c|c|c|c|}
\hline $\begin{array}{l}\text { Name of association, } \\
\text { shares or traders }\end{array}$ & Year(s) in E.C. & Total harvest (Q) & $\begin{array}{l}\text { Post-harvest } \\
\text { loss (Q) }\end{array}$ & $\begin{array}{l}\text { Post-harvest } \\
\text { loss (\%) }\end{array}$ \\
\hline Tekeze & $2001-2007$ & 8334.12 & 238 & 2.9 \\
\hline Kisanet & $2005-2007$ & 1128.88 & 23.9 & 2.1 \\
\hline Mamu and Abera & $2006-2007$ & 985.76 & 20.15 & 2.0 \\
\hline Guesh and Gersie & $2006-2007$ & 535.11 & 23.9 & 4.5 \\
\hline Equibon Dinkon & $2006-2007$ & 6100 & 200 & 3.3 \\
\hline Raey Meles & $2006-2007$ & 7786 & 260 & 3.3 \\
\hline Haleka Tsegay & 2007 & 135 & 5.5 & 4.1 \\
\hline Traders 1 and 2 & 2007 & 4195 & 295 & 7.0 \\
\hline Hashenge 1 & $2001-2007$ & 244.75 & 2.35 & 1.0 \\
\hline Hashenge 2 & $2006-2007$ & 93.27 & 2.83 & 3.0 \\
\hline Total & & $29,537.9$ & 1071.68 & 3.63 \\
\hline
\end{tabular}

sometimes forced the legal associations to sell their product below the expected price. Similar concerns have been reported and discussed by different authors [1,2]. Generally, physical, quality and market force losses occur throughout the post-harvest chain from harvesting to consumption. These result in loss of income and contribute to food insecurity [17].

In this study, about 112.98 quintals of fish post-harvest loss was recorded as physical loss from the road survey and observations during our field study for fish thrown away around landing sites, stores and roads of Tekeze dam fishery associations. This is in agreement with the reports explained for Kainji Lake Fisheries [26].

The knowledge, attitude and handling practice (KAP) of the respondents about fish post-harvest losses in the study areas were very good. Fish processing (filleting and gutting) was done under shade, under trees or in a cave, where quality post-harvest loss is possibly reduced. They easily distinguish between the spoiled fish and unspoiled fish and characterize losses using the signs and colour changes. The colour changes in scales or gills, eyes, texture and bad smell due to spoilage are among the signs the fishermen used to distinguish between bad and good fish quality. In our survey, most of the respondents explained and showed us practically that spoiled fish flesh becomes greenish, cloudy and whitish with a very soft texture and deteriorated appearance (Fig. 2a). In addition, the eye of spoiled raw fish becomes cloudy or dull and the gills' colour and texture become yellowish brown and rough, respectively (Fig. 2b). Such kinds of discolorations and fish spoilage due to handling problems were also discussed and reported by Akande and DieiOuadi [1], Cheke and Ward [2] and Mgawe [23]. Spoilage is defined as the sensory changes resulting in a fish product being unacceptable for human consumption. It is caused by autolytic and chemical changes or off-odours and off-flavours due to bacterial metabolism [27].

Throughout the study period, we tried to list out the potential fish post-harvest loss intervention strategies. Similarly, Ames [28] listed some fish post-harvest losses reduction actions and Clucas et al. [29, 30] described several ways of reducing losses in detail. Some of them are use of ice for fresh fish handling, distribution and marketing, improved drying practices, reducing insect infestation in fish processing and storage and good hygiene practices during fish processing.

Reducing post-harvest losses requires prudent use of resources, reducing spoilage and discards and converting low-value resources into high value products on a sustainable basis for direct human consumption. Reducing spoilage 
requires improved fish handling, processing, preservation and transportation systems, all of which are particularly deficient in small-scale fisheries like Tekeze and Hashenge. Similarly, according to Oyewo [31], improved quality of the product resulted in better market pricing and improved income, which translated into a reduction in economic loss. Moreover, speed and good hygiene are important factors in handling and processing. Reductions in poverty and malnutrition would be a major expected benefit of such integration and post-harvest loss reduction [32].

Additionally, much can be achieved by simple improvements in handling and processing methods. So the basic requirement for fish handling is to take more care as fish is easily damaged and easily spoiled. Careless procedures will accelerate spoilage and increase losses, but careful methods will retard spoilage, reduce losses and improve the quality of the marketed products.

Food security is a major concern for all countries in view of population increase and diminishing energy and water resources. Over one billion people in low- and middle-income countries suffer from malnutrition. To meet the UN Sustainable Development Goals to eradicate hunger and poverty, it is essential to reduce postharvest losses, including in the fisheries sector [33].

Globally, food losses and post-harvest waste are estimated at $30-40 \%$ of production [34]. Losses of perishable foods such as fruit and vegetables can be even higher during the post-harvest period, depending upon the weather, access to storage or distance from markets. Utilizing improved post-harvest practices often results in reduced food losses, improved overall quality and food safety, and higher profits for growers and marketers [35].

FAO [5] estimates losses for fisheries among the highest. This is also accompanied by financial losses since the spoiled or poorly processed fish are discarded or sold at a low price. The global demand for fish is growing rapidly, and reduction in post-harvest losses can make a major contribution to satisfying consumer demand through improved quality and quantity. Achieving this requires coordination and joint activity from all members from different economic sectors, production and business scales assisting members to improve value, quality and compatibility of fish products [36].

According to Campbell and Ward [37], many of the interventions aimed at improving product transformation are concerned with maintaining the quality of the product. Improvements in fish processing technologies are widespread such as improved fish smoking and drying methods. On the other hand, an intervention to reduce losses will function by either improving the quality of current output and/or increasing the quantity produced [25]. Any intervention must consider what the price increase will be to the final consumer and whether this increase is affordable by the poorest consumers. Necessary price increases can be estimated from the expected costs of the intervention, and market research can be used to show to what extent consumers will be willing to pay a higher price for a higher-quality product.

Fish preservation is a very important aspect of the fishery associations of the study lakes. However, the fishing grounds (fish capturing sites) are located far away from the storage places where refrigerators are available. There is therefore a high risk of increased fish deterioration which compromises its subsequent sale. In addition, there are challenges associated with shortage of refrigerators, particularly when they are full with unsold products. Fish can be preserved using several techniques to maintain the quality and to increase its shelf life. These include traditional fish processing and preservation techniques such as canning, freezing, cold storage, dehydration (salting, drying, smoking) and the use of chemical treatment [38]. However, these practices were not common in the study areas except refrigeration (freezing).

Post-harvest losses in small-scale fisheries can be among the highest for all the commodities in the entire food production system [5]. Fish losses caused by spoilage are estimated at 10-12 million tons per year, accounting for around $10 \%$ of the total production from capture fisheries and aquaculture. Appropriate preservation methods can significantly reduce this loss, during glut catches when the processing, distribution and marketing system cannot cope with the exceptional quantities of fish that are sometimes landed due to seasonal or interannual variations of availability or abundance [39].

The technology of freezing and chilling is too expensive for most rural fishery associations, and preservation techniques vary primarily in terms of capital requirements, technological complexity [40], raw material requirements and the nutritional and organoleptic quality of the processed products. For the fresh fish market, the use of specialized transportation methods such as refrigerated trucks is highly desirable.

Freezing of fish or fish fillet directly after catch more or less halts most of the enzymatic reactions, depending on the temperature of the frozen fish. However, during later thawing, chilled storage or further processing of the fish, glycolysis, proteolysis, lipolysis and other enzymatic reactions continue and may result in quality losses. Decrease in water-binding capacity and texture deterioration is examples of the effects of "thaw rigor" [41].

One of the challenges during preservation is water activity from the fish body because water is necessary for microbial and enzymatic reactions and several preservation techniques have been developed to tie up this water (or remove it) and thus reduce the activity of water. This means preservations are designed to inhibit or reduce the 
metabolic changes that lead to fish spoilage by controlling specific parameters of the fish and/or its environment [42].

\section{Conclusion and recommendations}

The fishery associations in the study areas experienced serious fish post-harvest losses due to poor post-harvest handling, storage and management problems. As such, careful treatment in handling and processing is paramount. Although the extent of the problem varied from place to place, the country as a whole is losing a significant amount of fish annually through post-harvest losses. This is a massive economic and nutritional waste, which in a country like Ethiopia is already in danger of protein malnutrition it can ill afford. The improvement of facilities from the point of production until it reaches the consumer is vital; for example, using retaining cages, decreasing fish harvest when refrigerators are full, making good arrangements and management of refrigerators, quickly reaching to storage area and refrigerated immediately, controlling refrigerators and separate the spoiled and healthy ones are some of the interventions recommended. Besides, it must be distributed under chilled temperatures using refrigerated trucks.

\author{
Abbreviations \\ FPHL: fish post-harvest losses; KAP: knowledge attitude and practice; LIFDCs: \\ low-income food-deficient countries; QLAM: Questioner Loss Assessment \\ Method.
}

\section{Authors' contributions}

The corresponding author carried out the responsibilities of proposal drafting, data collection and write-up of the manuscript. The co-author Dr. Mekonen Teferi, participated in activities like communicating with the associations, commenting on issues to be raised on the proposal and questioners and participating in the write-up of the manuscript. Both authors read and approved the final manuscript.

\section{Acknowledgements}

This study received financial support from the College of Natural and Computational Sciences (CNCS), Mekelle University. Fishery men of Tekeze and Lake Hashenge are acknowledged for their cooperation during the data collection. We are grateful to Mr. Belay Gebreyohanes and Yemane Kidane for their help during field data collection. Two anonymous reviewers are acknowledged for valuable suggestions that improved the manuscript.

\section{Competing interests}

The authors declare that they have no competing interests.

\section{Availability of supporting data}

We declare that whatever data have been used in the manuscript will kept remain intact. These data can be made available to anyone who desires to see them from the corresponding author on request.

\section{Consent for publication}

It is declared that the information given in the manuscript now can be published by the Publication House and Journal of "Agriculture and Food Security".

\section{Ethical approval and consent to participate}

It is to declare that we have all the ethical approval and consent to take participate in research paper writing and submission to any relevant journal from our organization where we are working and posted.

\section{Funding}

This work was funded by College of Natural and Computational Sciences

(CNCS), Mekelle University, from its recurrent budgets.

Received: 23 February 2016 Accepted: 9 December 2016

Published online: 15 February 2017

\section{References}

1. Akande GR, Diei-Ouadi Y. Post-harvest losses in small-scale fisheries. Case studies in five sub-Saharan African countries. FAO Fisheries and Aquaculture Technical Paper No. 550. Rome: FAO; 2010.

2. Cheke RA, Ward AR. A model for evaluating interventions designed to reduce post-harvest fish losses. Fish Res. 1998;35(3):219-27.

3. Adewolu MA, Adoti AJ. Effect of mixed feeding schedules with varying dietary crude protein levels on the growth and feed utilization of Clarias gariepinus fingerlings. J Fish Aquat Sci. 2010;5:304-10.

4. FAO. FAO/World fish Center Workshop on Interdisciplinary Approaches to the Assessment of Small-Scale Fisheries. 20-22 September, 2005. FAO Fisheries Report No.787. Rome: FAO; 2005.

5. FAO. Reducing post-harvest losses. Rome: FAO Fisheries and Aquaculture Department; 2010.

6. FAO/UNDP. Report to the government of Malawi on fish handling, preservation and distribution. Based on the work of Y. C. Gilberg. FAO/TA fish processing technologist. Rep. FAO/UNDP (TA).(2224); 1966. p. 52.

7. Geoffrey R. The kinds and levels of post-harvest losses in African inland fisheries. In: Proceeding of the symposium on post-harvest fish technology. CIFA Technical paper No 19. Rome, FAO; 1992. 1990. p. 1-9.

8. FAO. Securing regional supply in aquatic products: prospects from the FAO post-harvest loss assessment case studies. In Committee for Inland Fisheries and Aquaculture of Africa, Fifteenth Session. Lusaka; 2008.

9. Elvevoll EO. Fish waste and functional foods. Norwegian College of Fishery Science, Department of Marine Biotechnology, University of Tromso; 2007.

10. Kabahenda MK, Omony P, Husken SMC. Post-harvest handling of low value fish products and threats to nutritional quality: a review of practices in the Lake Victoria region. Regional Programme Fisheries and HIV/AIDS in Africa: Investing in Sustainable Solutions. The World Fish Center. Kampala: Department of Food Science and Technology, Makerere University; 2009.

11. FAO. The prevention of losses in cured fish. FAO Fisheries Technical Paper No. 219; 1981.

12. Eyo AA. Fish processing technology in the tropics. National Institute for Freshwater Fisheries Research (NIFFR); 2001.

13. United Nations Environment Programme (UNEP). The environmental food crisis - the environment's role in averting future food crises. In: Nellemann C, editor. The environmental food crisis: the environment's role in averting future food crises: a UNEP rapid response assessment. UNEP/ Earthprint; 2009.

14. Dad BF, Gnanados DAS. Nigerian fisheries development: challenges and opportunities of the 1980's. In: Proceedings of the 3rd annual conference of the Fisheries Society of Nigeria (FISON) Maiduguri; 1983. p. 14-24.

15. Tobor TG. Finfish and shellfish of conservation interest in Nigeria. In: Proceedings of the national conference on conservation of aquatic resources, edited by Eborgeal National Resources Conservation Council (NARESCON); 1993. pp. 104-29.

16. Teklu D. Determinant factors for wasted fish during harvesting at Amerti and Fichawa Reservoirs Oromia/Ethiopia. J Fisheriessciences.com. 2015;9(4):012-5.

17. Diei-Ouadi Y, Mgawe YI. Post-harvest fish loss assessment in small-scale fisheries: a guide for the extension officer. FAO Fisheries and Aquaculture Technical Paper. No. 559. Rome: FAO; 2011.

18. Fraser OP, Sumar S. Compositional changes and spoilage in fish (Part II) microbiological induced deterioration. Nutr. Food Sci. 1998;98(6):325-9.

19. National Statistics of Ethiopia (NSE). Climate, Length of Major Rivers in Ethiopia; 2008.

20. Mulu BD, Abraha GA, Yirgalem WG. Health risk assessment of heavy metals bioaccumulation in water, sediment and three fish species (Labeobarbus spp., Clarias gariepinus and Oreochromis niloticus) of Tekeze river dam, Tigray, Northern Ethiopia. J Atmos Earth Environ. 2012;1(1):19-29. 
21. Haileselasie TH, Mekonen T, Tadesse D, Kiros W, Gebru E, Solomon A, Tsegaluel A, Solomon T, Kokob G, Kokob K. Investigating the opportunities for enhancing freshwater fish production to integrating aquaculture and fisheries into rural development in Inland areas: (A case study in small reservoirs in Mekelle Vicinity and Lake Hashengie of Tigray, Northern Ethiopia). Curr Res J Biol Sci. 2012;4(4):401-6.

22. Omwega RN, Abila R, Lwenya C. Fishing and poverty levels around Lake Victoria (Kenya). Kisumu: Kenya Marine and Fisheries Research Institute; 2006.

23. Mgawe IY. Postharvest fish loss assessment on Lake Victoria sardine fishery in Tanzania-Rastrineobola Argentea. FAO Fisheries and Aquaculture Report, No. 904; 2008. p. 85-96.

24. Affognon $H$, Mutungi $C$, Sanginga P, Borgemeister C. Unpacking postharvest losses in sub-Saharan Africa: a meta-analysis. World Dev. 2015;66:49-68.

25. Poultry RG., Ames GR, Walker DJ. Post-harvest losses in traditionally processed fish products. In: The First Indian Fisheries Forum: proceedings, December 4-8 1987 Mangalore; 1988.

26. Eyo AA. Post harvest losses in the fisheries of Kainji Lake. NigerianGerman Kainji Lake Fisheries Promotion Project, Technical Report Series 5: 1997; ISSN: 1119-1449.

27. Huss HH. Control of indigenous pathogenic bacteria in seafood. Food Control. 1997;8(2):91-8.

28. Ames GR. The kinds and levels of post-harvest losses in African inland fisheries. In: Proceedings symposium post-harvest fish technology. Cairo; 21 Oct 1990. p. 21-22

29. Clucas IJ (Compiler). Fish handling, preservation and processing in the tropics: part 1. Report of the Tropical Development and Research Institute; 1981. G.144, vii+141pp.

30. Clucas IJ (Compiler). Fish handling, preservation and processing in the tropics: part 11. Report of the Tropical Development and Research Institute); 1982. G.145, vii+144pp.

31. Oyewo EO. A profile on Orimedu coastal fishing community, IbejuLekki Local Government Area of Lagos State, Nigeria. In: Rajagopalan R,
Lakshmi A, editors. Coastal Community Study Papers. International Ocean Institute; 2001.

32. Karim $M$. The livelihood impact of fishpond integrated within farming systems in Mymensingh district, Bangladesh. Ph.D. Thesis. Institute of Aquaculture. University of Stirling; 2006

33. Assembly UG. Transforming our world: the 2030 Agenda for Sustainable Development. Resolution adopted by the General Assembly on 25 September 2015. New York: United Nations. http://www.un.org/ga/search/ view_doc.asp; 2015.

34. Gustavsson J, Cederberg C, Sonesson U, Van Otterdijk R, Meybeck A. Global food losses and food waste. Rome: Food and Agriculture Organization of the United Nations; 2011

35. Kitinoja L. The Postharvest Education Foundation. www.postharvest.org; 2014

36. Adeokun OA, Adereti FO, Opele Al. Factors influencing adoption of fisheries innovation by artisanal fishermen in coastal areas of Ogun State, Nigeria. J Appl Sci Res (INS Inet Publication). 2006;2(11):966-71.

37. Campbell J, Ward A. Fisheries post-harvest overview manual. An output of the DFID-funded Post-Harvest Fisheries Research Programme produced by IMM Ltd, Exeter; 2004.

38. Oguntimehin GB. Preservation through the application of energy (heat processing, Freezing, drying and radiation). Proc Niger Food J. 1985;2:76-81.

39. FAO. Quality and quality changes in fresh fish. FAO Fisheries Technical paper No. T348. Rome: FAO Fisheries and Aquaculture Department; 1995.

40. Igene JO. Notes on the traditional methods of fish preservation in Nigerian sector of Lake Chad. Proc Fish Soc Niger. 1983;3:123-30.

41. Rehbein $\mathrm{H}$, Oehlenschlager J, editors. Fishery products: quality, safety and authenticity. New York: Wiley; 2009.

42. FAO 2005-2015. Fisheries and Aquaculture topics. Preservation techniques. Topics Fact Sheets. Text by Lahsen Ababouch. In: FAO Fisheries and Aquaculture Department [online]. Rome. Updated 27 May 2005. [Cited 23 Oct 2015]. http://www.fao.org/fishery/topic/12322/en.

\section{Submit your next manuscript to BioMed Central and we will help you at every step:}

- We accept pre-submission inquiries

- Our selector tool helps you to find the most relevant journal

- We provide round the clock customer support

- Convenient online submission

- Thorough peer review

- Inclusion in PubMed and all major indexing services

- Maximum visibility for your research

Submit your manuscript at www.biomedcentral.com/submit
O Biomed Central 